\title{
COLLATERAL DAMAGE OF OIL THEFT: THE LEGAL WAY OUT
}

\author{
C.O. Okwelum, PhD \\ Department of General Studies, \\ School of humanities \& social Sciences, \\ Delta State Polytechnic, Ozoro \\ $+\mathbf{2 3 4 8 0 7 5 6 8 4 2 7 4}$
}

\begin{abstract}
The Niger Delta of Nigeria has since acquired the first position in the world for notorious oil theft. The complicities of the military and the multinational oil companies in the crime have equally been well articulated. This paper addresses the relationship that exist between the corridors of oil theft and the collateral damages attendant on the scourge of oil theft since same acquired an industrial and international status in the delta. It reviews the various ways the theft has manifested and employs the doctrinal research methodology. It critically examined the findings of the Chatham House and the Ribadu's Committee and keys more particularly into the prescriptions advanced by the Guardian to the effect that instead of 'blowing up things' through the military, the state ought to find ways of structuring illegal refineries in the creeks into efficient production units underlined by quality control.
\end{abstract}

Keywords: Niger Delta, Oil theft, Illegal Refineries, Military and Collateral Damages. 


\section{Introduction}

The Brass-Akassa corridor on the Atlantic fringe has been identified as a notorious spot for crude oil theft by the country's security operatives. ${ }^{1}$ To Akinosho Toyin the flawed implementation of the amnesty programme of the Federal government is the cause of oil theft in the Niger Delta arguing that the theft began in 2001, morphed into militarization with kidnapping. The poor workability of the amnesty programme has now ushered in vandalism again and theft; and 'when you are giving a thief a job, it does not send the right signal out, it encourages brigandage.' 2 Yet the trio of Amaize, Oyadonga and Onoyume ${ }^{3}$ consider Nigeria to be in dire straits. Having been reporting on the oil industry sector over the years, they have acquired a certain high degree of authority and the result of their investigative journalism is that very highly placed individuals are involved in the conspiracy involving high technologycrime with well built cartels responsible for oil theft in Nigeria.

In their analysis, the cartels are highly connected people in and outside government, oil companies, businessmen, retired and serving military officers including people you may never have thought could be involved bleeding the country dry. Those who steal crude oil from well heads with cotonou boats and then hide in the bush in the creeks to refine and sell to petrol stations owners are a group. They are in the kindergarten section of the business. The main culprits are the ones unseen. They do not go to the pipelines to hack and steal crude oil. They do their transactions at the various oil terminals. Whether at Forcados or Bonny, officials can declare that only two vessels were loaded when ten were loaded. They ask, 'do you think anybody will be complaining of stealing of crude oil if it is just the volume that villagers steal and refine to eke a living?'

\section{Military Complicities}

Oil cartels have illegal points where they siphon oil through long hoses into their waiting boats with an understanding with military officials. For instance in July, 2013 the Joint Military Task Force (JTF) discovered three illegal crude oil loading points one each at Igbomotoru, Oyeregbene and Mbikiba in Delta State and urged Agip to carry out an assessment on the illegal loading points before having them sealed up. ${ }^{4}$ 'The poor class who were doing the business to earn a living have long quit the business because of the manhunt by security agents, who destroy their properties as they could not afford huge amounts to settle the agents on a daily or monthly bases as the cases may be,' the trio of Amaize, Oyadonga and Onoyume report. ${ }^{5}$

\footnotetext{
${ }^{1}$ Oyadongha, S., Grounded Crude Oil Barge: Navy Arrests Tug Boat, 6 Suspects.

${ }^{2}$ Akinosho, T., The News Interview: Flawed Implementation of Amnesty Programme Caused Oil
}

Theft in the Niger Delta. http://mobile.saharareporters.com. April 15, 2013.

${ }^{3}$ Amaize, E., Oyadonga, S., and Onoyume, J., Oil: The Conspiracy that Robs Nigeria of Billions of Dollars. www.vanguardngr.com. August 25, 2013.

\footnotetext{
${ }^{4}$ Asu, F., JTF Discovers Illegal Crude Loading Points, Impound Barges. http://businessdayonline.com. July 4, 2013.

${ }^{5}$ Amaize, E., Oyadonga, S., and Onoyume, J., Oil: The Conspiracy that Robs Nigeria of Billions of Dollars. www.vanguardngr.com. August 25, 2013.
} 
Military men see the business as a money-making venture. They lobby to be posted to the Niger Delta creeks in order to make illicit fortunes to buy expensive cars and build large houses. Oil men lobby military men in oil installations to enable them load raw crude from points and to refine paying N100,000 to N200,000 per boat and local refinery operators settle military men in their operational areas with $\mathrm{N} 1$ million to N2 million per week. Most military men, government officials and oil company workers have big vessels, cotonou boats, barges, local refinery ports and illegal points allocated to individuals to steal oil and make huge amounts of money. They are selective in their operations. They only go after people who refuse to settle them. ${ }^{6}$

Oil theft in Nigeria is a huge criminal operation affecting companies and states around the world. It is a genre of organized crime that is almost totally off the international community's radar. Without better knowledge of how the stolen oil trade works, not every government can ignore it with confidence. But interest in tackling the problem is low. The quantity stolen is disputed according to Chatham House. ${ }^{7}$ Varying from $150,000 \mathrm{bpd}$ and above; and costing \$6 billion annually, proceeds are laundered through world financial centers and used to buy assets in and outside Nigeria. To Chatham House, politicians, military officers, militants, oil industry personnel, oil trader and communities profit from the industrial theft. It is not only being stolen from pipelines but from tank farms, export terminals, refinery storage tanks, jetties, ports, and wellheads. ${ }^{8}$

However, oil theft manifests in three ways: Firstly, the ordinary people who cut the pipes and put it in jerry cans and go and heat it in some form of illegal and or artisanal refineries. This group is prevalent in the Niger Delta. Secondly, is the group which puts the crude oil in barges and sell it. Thirdly, is the group which is stationed with big vessels in the high sea and sell it abroad. ${ }^{9}$

Cracking down on those involved could inflame tensions amongst powerful figures in southern oil producing Niger Delta region where unrest declined after the 2009 amnesty proclamation on rebels but stability remains elusive. Companies had in recent times sold onshore assets seemingly to focus on deepwater projects where the risks of theft and unrest are limited. The initial stages of Nigerian crude theft are largely known, with gangs tapping into pipelines pumping crude to smaller vessels which take it to larger ships and barges for international sale. Chatham House believed it was less clear where the illicit crude is taken abroad and how it gets there. It partly reaches world markets through 'co-loading' where stolen oil is put on ship carrying legal oil. Documents are forged and the vessel departs seemingly laden with legitimate cargo. ${ }^{10}$

\section{Chatham House Findings}

Chatham House's investigation which was based on interviews of over 200 government, private sector and independent sources and reviewed thousands of documents concluded that

\footnotetext{
${ }^{6}$ Id.

${ }^{7}$ Chatham House (London Royal Institute of International Affairs): Lagos (AFP), Nigerian Crude Oil Stolen on an Industrial Scale. www.vanguardngr.com. September 20, 2013.

${ }^{8}$ Vidal, J., F1bn a month: The Spiraling Cost of Oil theft in Nigeria. www.theguardian.com. October 5, 2013.

${ }^{9}$ Ahamefula, O., Nigeria: Oil theft - We are yet to Catch the Big thieves, says Mittee. http://m.allafrica.com/stories. October $14,2013$.

${ }^{10}$ Lagos (AFP), Nigerian Crude Oil Stolen on an Industrial Scale. www.vanguardngr.com. September 20, 2013.
} 
the USA may not be the leading destination for illicit cargo because US refineries more rigorously inspect incoming crude cargo. Refineries in regional markets like Cameroon, Ghana and Ivory Coast are listed as likely buyers and collaborators. Refineries in China, India, Singapore and Eastern Europe all purchase stolen Nigerian oil but the think tank found little direct evidence in support of any specific charge. ${ }^{11}$

According to the London-based research group, oil is being stolen on an industrial scale and Nigeria's politicians and security officials are profiting and many have attributed the major cause of crude oil theft to pipeline vandalism but the problem is more than pipeline vandalism as substantiated by the Ribadu Committee. According to Felix Ayanruoh, ${ }^{12}$ not much that is serious is heard about the real cause of oil theft or what stakeholders in the industry are doing to stem the scourge because crude theft involves a convoluted and complex web of relationships spanning all levels of the society involving diverse relationships. These relationships are alleged to include highly connected people in and outside government (members of the executive and legislature), oil companies (including the NNPC), businessmen, retired and serving military officers and militants among others. ${ }^{13}$

\section{Oil Company Complicity: A Shell Example}

The complicity of Shell and the military in the Trans Niger Oil Pipeline thefts, for instance, can be borne out by the statements of the Official Observer for the Bodo investigation ${ }^{14}$ Reverend Father Obi had stated: 'I am personally sure that Shell knew that its oil was being stolen. If Managers did not know, then those they put in charge seemed to know. This theft could not have happened without the collusion of the authorities and the military. If they do not publish their report, I will publish mine.' The Catholic Reverend Father queried: 'Why was a massive barge able to hold 10,000 barrels of oil being loaded at 2 am with crude? Why were local observers arrested the next day? Why were their cameras confiscated and memory cards destroyed? Were the thieves not being protected by the military?'

However, if there is any multinational that is alive to its publics yet most criticized, it is Shell. Shell's level of response to the Bodo explosion and its plight generally in the Niger Delta is not only admirable but forthright. Mutiu Sunmonu and Phillip Mshelbila ${ }^{15}$ of Shell state: 'Unknown persons continued to reconnect illegal bunkering hoses at Bodo West even as our pipeline team was removing crude theft points.' 'One has to understand that there is this accusation that the oil industry employees are behind this, but there are thousands of people who have the skills who may have been working with the industry over the years. These people are outside and some of them may be for hire.' And 'The success of any interim measure and final remediation depend on the cessation of oil theft and illegal refining in the area which re-impacts the environment and remains the cause of most oil pollution in the

\footnotetext{
${ }^{11} \mathrm{Id}$.

${ }^{12}$ Ayanrouh, F. Nigeria -Cold Facts of Crude Oil Theft. www.vanguardngr.com October 15, 2013. See also, Chatham House, Nigeria Oil theft a Global Criminal Enterprise.http://pmnewsnigeria.com. September 19, 2013.4

${ }^{13}$ Ayanruoh, F., Nigeria - Cold Facts of Crude Oil Theft. www.vanguardngr.com. October 15, 2013.

14 14.Vidal, J., F1bn a Month: The Spiraling Cost of Oil Theft in Nigeria. www.theguardian.com. October 5, 2013.

${ }^{15} \mathrm{Id}$
} 
Niger Delta. ${ }^{16}$ The Bodo explosion was significant in that it showed how oil theft in Nigeria had reached an industrial scale and ranks with the drugs trade as the most lucrative crime in the world. ${ }^{17}$

But Asobie ${ }^{18}$ has a point against the benign disposition of Shell to its publics in the face of its plight in the Niger Delta business environment. He argues that the multinationals are not just oil companies, they are joint venture companies which means that they are in collaboration with the indigenous people who have masters in politicians, military officers, foreigners, militants, who steal. In other words, the sophistication of Shell in explaining its predicament to its publics should be taken with a pinch of salt as a distinction ought to be made between the ordinary vandals who roughly break the pipelines out of need, frustration and desperation and the sophisticated stealing of the oil companies. For instance, Asobie canvasses that it is true that there is sophisticated oil stealing: 'I think what happens is that when it comes to lifting, when they are not properly supervised, they give figures of what they have lifted, which is often not as good as what is actually lifted. ${ }^{19}$ Furthermore, officials and private actors disguise theft through manipulation of meters and shipping documents. ${ }^{20}$

There is a certain high degree and level of synergy and complicity between those who are supposed to check oil theft and those perpetrating it and this relationship is being underrated. One of John Vidal's findings (through an interviewee) is that:

'A lot of big-time stealing goes on. You know the oil you are offered is stolen. They give it to you without documents at a cheaper rate. I was offered 50,000 liters for N55 a liter instead of N75 government rate. There is no chance getting caught because there is no system to catch people.'

Vidal submits that the Nigerian military has become deeply implicated in oil theft since the amnesty proclamation and the military instead of the militants now controls the oil platforms. Thieves now have to buy oil directly from the military which is a chain of command. It is far easier to go straight to the military. ${ }^{21}$

Under interview, Mittee Ledum ${ }^{22}$ volunteered further that

'You need to see how big some of these barges are and they move from here to the sea and if you want to transport yourself from here to that place, you know how many security check points you are going to pass through there and then you find that not much is happening in those areas. Our law enforcement is clearly compromised.' 'Our law enforcement dragnet has not been able to catch the fishes, because in a system

\footnotetext{
${ }^{16}$ Vidal, J., Niger Delta Oil Spill Victims Reject 'derisory' Shell Compensation Offer. www.theguradian.com . September 13, 2013.

${ }^{17}$ Vidal, J., F1bn a Month: The Spiraling Cost of Oil Theft in Nigeria. www.theguardian.com. October 5, 2013.

${ }^{18}$ Olayinka, C., Nigeria is oil-dependent, not oil-rich, says Asobie. www.ngrguardiannews. October 16, 2013.

${ }^{19} \mathrm{Id}$

${ }^{20} \mathrm{Id}$

${ }^{21} \mathrm{Id}$

${ }^{22}$ Ahamefula, O., Nigeria: Oil theft - We are yet to Catch the Big Thieves, says Mittee. http://m.allafrica.com/stories. October 14, 2013.
} 
like ours, if you go fishing and you lay your nets, when big fishes come, they tear the net and pass, but you can catch the smaller ones. So, we need to enforce a system that will ensure that whoever is involved will be caught.'

\section{Why Rationalizing Oil Theft?}

Paul Michael Wihbey ${ }^{23}$ argues that the surge in oil theft could be linked to the fatal error of non passage of the 2011 version of the Petroleum Industry Bill. It recommended ten percent equity stake for host communities in the Niger Delta. He believes that oil theft cannot be resolved through security means (JTF) as long as oil producing communities continue to wallow in abject poverty. ${ }^{24}$

Wihbey's position is almost in tandem with that of Ebikabowei Victor Ben (Boyloaf) ${ }^{25}$ who argues that oil theft in the Niger Delta will not stop until the Federal Government takes appropriate steps to compensate the various natives of the region. This is because the owners of the land where the oil facilities crisscross do not feel any sense of belonging after many decades of oil production. Ebikabowei, a well acknowledged militant, states: 'I hate to hear the word "oil thieves or oil theft" because the people you want to label as thieves are simply trying to make use of their God-given resource.' In other words, what they are doing is the legitimate 'resource control.' In Nigeria is Oil-dependent, not Oil-rich, Boyloaf's thesis was further amplified by Assisi Asobie ${ }^{26}$ that more importantly, the people of the Niger Delta are stealing oil because they realize that stealing is going on at the highest level of government not only of oil but oil money. They regard oil theft as informal tax; they do not look at it as stealing.

But Boyloaf's thesis does not bode well in law. Not only is it an act of robbery against the State, it contributes to heightening the bitter acrimonies and divisions among Nigeria people. For Obadiah Mailafia, ${ }^{27}$ the north and other regions may feel that a region that already enjoys such largesse is also the hub of criminal oil theft on such a staggering scale: 'To those who have, it seems, are granted opportunity to take even more through the backdoor' dovetailing into northern resistance and militancy in form of Boko Haram.

It has been convincingly argued that the Boko Haram militancy in the north eastern part of Nigeria particularly in the old Kanem Bornu Empire is an extension of the oil war in the Niger Delta. Adewale Maja-Pearce ${ }^{28}$ in the New York Times in Nigeria's Long Emergency, revealed how General Mohammed Buhari correctly captured the state of affairs that Niger Delta militants 'were given money and a training scheme was introduced for their members' while in contrast, 'when Boko Haram emerged, members of the sect were killed'.

\footnotetext{
${ }^{23}$ Ebiri, K., How Bunkering puts Nigeria's Oil Export in Jeopardy. www.ngrguardiannews. September 29, 2013.

${ }^{24} \mathrm{Id}$

${ }^{25}$ Daniel, S., Why Niger Delta Oil Theft can't Stop - Boyloaf. www.vanguardngr.com. September 7, 2013.

${ }^{26}$ Olayinka, C., Nigeria is Oil-dependent, not Oil-rich, says Asobie. www.ngrguardiannews. October 16, 2013.

${ }^{27}$ Obadiah, M., Nigeria's oil pillage crisis. http://businessdayonline.com. September 30, 2013.

${ }^{28}$ Adewale, M., Nigeria's Long Emergency, http://mobile.nytimes.com. September 22, 2013.
} 
Obadiah $^{29}$ therefore canvasses rightly that when we accept criminality as part of the natural order of things, we create an atmosphere where lawlessness becomes the accepted norm. The death of public reason often presages the death of the rule of law, which in turn paves way for the death of free republics. Christina Katsouris and Aaron Sayne of Chatham House (London Royal Institute of International Affairs) have also reached the same conclusion that corruption and fraud are rampant in the oil sector. A dynamic, overcrowded political economy drives competition for looted resources. Poor governance has encouraged violent impunity and opportunism around oil and opened doors for organized crime. ${ }^{30}$

Debunking the Ebikabowei Boyloaf thesis further, Nasir El-Rufai ${ }^{31}$ canvasses that virtually everyone in Nigeria is taking the laws into his hands because the state has failed to establish the rule of law and practice its tenets. He raises the question: While we respect the rights of all citizens including militants to demand for better governance and their rights to fight to protect the environment from the predatory activities of multinational oil companies, should we condone brazen theft, criminality and violence while rewarding the conduct with cash hand-outs? The obvious response is in the negative. Any state that chooses to reward bad behaviour or buy off those that take up arms against it with a blank cheque book should expect to see more and more of its citizens queuing up.

\section{Collateral Damage of Oil Theft}

Starting in October, 2012 Nigeria experienced a large spike in piracy off its coast. By early 2013 it became the second most pirated nation in Africa next to Somalia with MEND (Movement for the Emancipation of the Niger Delta) being fingered. And since October 2012, it has hijacked 12 ships, kidnapped 33 sailors and killed 4 oil workers. ${ }^{32}$ Ex-Governor Dickson $^{33}$ of Bayelsa State has observed that perpetrators of illegal bunkering, sea piracy and pipeline vandalism act with impunity to undermine constituted authority: 'What is happening is more of a threat to national security than loss of revenue...the violence, brigandage and criminality that we experience in the Delta... have their roots in the creeks.'

'It is from the creeks they have the easy funds to recruit followers; it is from these activities of crude theft and illegal refining that people are able to sustain such large number of youths following recruited into cult groups.' But hard times await them according to the Flag Officer Commanding the Central Naval Command of the Nigerian Navy ${ }^{34}$ in that efforts are being

${ }^{29}$ Obadiah, M., Loc. Cit.

${ }^{30}$ Chatham House, Nigeria Oil Theft a Global Criminal Enterprise. http://pmnewsnigeria.com. September 19, 2013.

${ }^{31}$ El-Rufai, N. A., Impunity, Injustice and Insecurity: What is the Role of Law? http://premiumtimesng.com. May 23, 2013.

${ }^{32}$ Conflict in the Niger Delta. http://en.m.wikipedia.org/wiki.

${ }^{33}$ Ese, S., Illegal Bunkering Cause of Arms Build up, says Dickson. www.businessdayonline.com. July 9, 2013.

${ }^{34}$ Ebenezer, A., Hard Time Awaits Criminal on Niger Delta Waterways - Naval Boss. www.tribune.com.ng. October 12, 2013. 
made to reach out to the coastal communities where crime and criminalities are being perpetrated in form of crude theft, illegal bunkering, illegal oil refineries, oil pipeline vandalism, piracy and sea robbery among others.

But the militants are not taking the state-centric security apparatuses lying low. According to Ojakorotu Victor, who urged for dialogue instead of threats on the part of the state-centric security arsenal, the proliferation of arms encourages oil theft leading to 150,000 barrels of oil being stolen daily since 2008 by militants and their foreign collaborators. And from 2008 to 2009, 33 Joint Military Task force (JTF) personnel have been killed, 38 missing, 55 wounded, 5 military gunboats destroyed, 3 seized, 24 automatic weapons and 579 rounds of ammunition captured. Militants have attempted to shoot down a naval helicopter and an Airforce helicopter and 11 soldiers have been killed. ${ }^{35}$

On the other hand, the military task force of more than 6,102 soldiers and police deployed in 2012 to the Delta consisting of about 70,000 sq kilometers to curb oil theft and protect facilities destroyed 1,819 makeshift or artisanal or illegal refineries, set ablaze 861 boats carrying as much as 20,000 liters each of illegally refined crude and 51 tanker trucks. ${ }^{36}$ Earlier, the task force had put into complete extinction, not fewer than 218 illegal refineries in the creeks stating that all the apparatus used to perpetrate these illegalities were destroyed while about 151 surface tanks and oil pumps were also destroyed. It also destroyed 159 wooden cotonou boats each of which had 20,000 liters capacity along with 27 barges used to convey illegal stolen crude oil to illegal refineries. The task force recovered 37 detonators used to burst pipes, gigantic hoses, generators, pumping machines and gas cylinders. The raids were around Oporoza village, Escravos in Delta, Alakri Waterside and the adjoining creeks of Sombreiro River at Abonema in Rivers State. ${ }^{37}$

Again, in 2013 the Nigerian Navy destroyed over 50 illegal refineries in the deep mangrove swamp near Otumara community in Warri South West Council Area of Delta State. The site was the largest collection of illegal refineries so far in Delta State with equipment and refined products worth billions of naira and the act was a major breakthrough in the war against oil theft and illegal refinery operators. ${ }^{38}$ Above all the JTF had claimed that it destroyed over 6,000 illegal refineries in 2011..$^{39}$

\section{Deregulation Argument and Privatization}

The argument for deregulation has been pointedly brought to the fore by Gabriel Ogbechie of Rain Oil that the Nigerian oil and gas industry is highly regulated by government which determines how much the investor buys the crude and how much the investor sells the refined

35 Ojakorotu, V., Military and Oil Violence in Niger Delta. Journal of Energy Security. www.ensec.org. August 27, 2009.

${ }^{36}$ Flash: Pollution Escalates in Niger Delta as Military set Ablaze 1,819 Illegal Refineries, 861 Boats Carrying Crude, 51 Tanker Trucks. http://newsbytesnow.com. August 16, 2013.

${ }^{37}$ Adeola, Y., JTF Destroys Largest Illegal Refineries' Site in Niger Delta.

${ }^{38}$ Editorial, Illegal Refineries in Niger Delta. www.ngrguardiannews. February 3, 2012.

${ }^{39} \mathrm{Id}$ 
crude so that the margin is fixed. And in such a scenario, before an investor can actually build a refinery and prosper, the investor must be able to sell at the investor's price. But government determines the price whereas crude oil which is the input is dollar denominated and it is sold at the internationally quoted price. He argues:

'So if you have a refinery, government will sell crude oil to you at the international price and the price of your output which is petrol, diesel and kerosene will be determined by government. So, there is a gap. If you have a refinery and government is giving you crude oil at international market rate, how are you going to sell your refined petroleum products? So there are still a lot of policy issues that will need to be clarified before people can actually go into spending money in building refineries. Once the policy framework is right, no one would need conviction to building refineries. $^{40}$

For Austin Oniwon, ${ }^{41}$ running a private refinery in Nigeria is not feasible. The cost and loss of mining could be so enormous for an investor to survive and cannot happen before the removal of oil subsidy. It is only government that can withstand the financial rigor and loss in venturing into refining crude oil. 'Nobody would buy crude oil at international market and sell below same. That is why private refineries are stalled.' For Zacheaus Opafunso, the government monopolizes the industry. There is no liberalization of the domestic crude oil market and competition from independent refineries to improve supply which practices are not sustainable. ${ }^{42}$

An investigative report carried out by Roseline Okere ${ }^{43}$ met substantially with the same responses and reactions: It is believed that deregulation is the best way forward for the oil and gas industry and the country because if the sector is deregulated, private operators would be able to build new refineries and there would be healthy competition. Investors cannot go into refining because the business environment is not conducive. The banks are not ready to give out loans for such investment and they cannot approach their shareholders. There are so many loopholes: The quantity of fuel being brought into the country is unknown; smugglers are smuggling fuel into the country on a daily basis; it would not be easy to compete with big refineries outside the country; all over the world, refineries are being sold off because of competition. $^{44}$

One of the banes of private refineries is lack of deregulation. A deregulated oil sector will open more private sector investments as more players would be attracted into the sector as against the present situation where it is regulated and under Government's control. More investments in this context means that more private refineries and other petrochemical

\footnotetext{
${ }^{40}$ Ogbechie, G., Subsidy Probe spurs new Downstream Investments - Rain Oil CEO. http://mobile.punchng.com. August 1, 2013.

${ }^{41}$ Essiet, D., How to make Private Refineries Viable. www.thenationonlineng.net. December 12, 2011. ${ }^{42} \mathrm{Id}$

43 Okere, R., How Investors Stall Government's drive for Private Refineries. www.ngrguardiannews.com.

December 9, 2012.

${ }^{44}$ Id
} 
industries would be set up and this would consequently bring down fuel prices. ${ }^{45}$ The same argument has been canvassed elsewhere that Government is willing to give licenses to private refineries since the four existing ones are not meeting the nation's needs and if there are enough refineries operating, there would be no importation. ${ }^{46}$

The Idika Kalu National Refineries Special Task Force conducted a diagnostic review of the four refineries existing in Nigeria and advised on the best approach to turn them around. It advised the government on private refineries licensing and partnership models for Greenfield refineries. The committee recommended that government should divest its equity from the refineries and allow private entities to manage them. It revealed the dismal state of the Government refineries and made a watertight case for the sale of the moribund state owned refineries. Of the 42 oil refineries in Africa, 3 in Nigeria had the worst performance efficiency and capacity utilization. Why is it that oil firms in the country run oil refineries elsewhere and refuse to do so successfully in Nigeria? The Idika Team argued forcefully that it was not the right thing to do for government to build new refineries or even repair the existing ones and according to Okonjo-Iweala, emphasis should have been to encourage all the private companies which had been hitherto granted license to endeavour to actualize the dreams instead of placing obstacles in their ways.

The Idika Team ${ }^{47}$ canvassed that the Federal government needed to create an enabling environment to encourage the private sector through incentive packages for the establishment of private oil refineries for domestic consumption and export. The stringent requirements for the establishment of private refineries must be removed. All that should be required should be proof of funding for the project, technical capacity, refinery configuration and products specifications for the refinery and evidence of land allocation. All over the world, refineries are changing hands. Nigeria should sell her own, the team proposed: 'Let the buyers of the obsolete Nigerian Refineries use their money to do TAM as were the cases with Delta Airline and Phillips refinery deals. This grand fraud must end'. ${ }^{48}$

These positions are further reinforced by Mittee Ledum. He canvasses that no reason exists why people should advocate that it is a national pride to have four refineries that are not working. All smaller countries around like Niger, Chad are refining. He argues:

'Who are we that things do not work with us? Any person who wants to do refinery should go and buy the oil and refine it and if we are giving it to you to refine and you can't, then we sell it. If we find that our refineries are not working well, either we sell

\footnotetext{
${ }^{45}$ Adekunle, O., Replicating the Gains of Deregulation in Petroleum Sector (2). www.vanguardngr.com. January 1, 2012.

${ }^{46}$ FG to Approve Licenses for Private Refineries says Jonathan. http://www.premiumtimesng.com.

${ }^{47}$ Jonathan, Sell the Refineries now. http://mobile.punchng.com. August 18, 2013; and AmanzeNwachukwu, C., FG may Dump Bayelsa, Kogi Greenfield Refinery Projects as only Lagos Viable. www.thisdaylive.com August 25, 2013. See also, Audu, L.O., Sepecial Report: Crude refining in Niger Delta communities. www.westafricainsight.org . January, 2013.

${ }^{48} \mathrm{Id}$
} 
the refineries or carry the crude and sell... We do not even get our refining to the last point... we are losing something' in terms of by-products'. ${ }^{4}$

On the strength of the arguments for privatization, 23 new licenses were approved by the Government in 2012. Twenty went to the private sector while the Federal Government and Chinese investors undertook to build additional refineries in Kogi, Lagos and Bayelsa. Initially, the up-front payment was huge. It was reduced in line with investors' expectation yet investors still failed to show serious commitment. Raising funds locally was obviously a problem as bank interest rates of $20 \%$ was suicidal. Foreign loans required sovereign guarantees that government did not consider necessary. Others demanded free market pricing policy that eliminated subsidies as the uncertainty and time lag related to subsidy refund could jeopardize the ultimate success of such ventures. ${ }^{50}$

\section{Theft and Aging Infrastructure Debate}

Bunkering, another word for oil theft, is the highly dangerous and illegal practice of people breaking into pipes to tap some of the oil which they can sell on the black market. Shell and Eni, the two major multinationals with the most on-the -ground coverage attribute most of the spills in the country to bunkering. Environmental activists on the other hand argue that the aging oil facilities are more to blame. In fact, Amnesty International and Friends of the Earth International have filed an official complaint against Shell before OECD (Organization for Economic Cooperation and Development) for breaches of the basic standards for responsible business in that Shell uses misleading and discredited information totally lacking in credibility to blame majority of its oil pollution on sabotage to the tune of $98 \%$ with the underlying legal implication that under the Nigerian law, when spills are classified as being the result of sabotage, Shell has no liability with respect to compensation for damage done to people or their livelihoods. ${ }^{51}$

The pipelines are as old as the oil operations that began more than 50 years ago and many are on the surface and under pressure 24 hours a day carrying oil for the past 50 years. The companies have only recently started to do replacements of their corroded pipes. ${ }^{52}$ In other words, it is a notorious fact that a lot of the infrastructure is aging and was built above ground thereby making it easier for criminal elements to break the pipelines and carry out illegal activities. $^{53}$

${ }^{49}$ Ahamefula, O., Nigeria: Oil theft - We are yet to Catch the Big Thieves, says Mittee. http://m.allafrica.com/stories. October 14, 2013.

${ }^{50}$ Six New Refineries Hurray! But not yet Uhuru. www.vanguardngr.com. July 9, 2012.

${ }^{51}$ Shell accused over Misleading Figures on Nigeria Oil Spills. www.amnesty.org/en/news. January

$25,2011$.

${ }^{52}$ Nigeria: Poor Oil Spill Clean-up Methods Affect Niger Delta Communities. http://m.irinnew.org/report. February 7, 2008.

${ }^{53}$ Olayinka, C., South-South Governors lead Campaign for Passage of PIB. $\quad$ www.ngrguardiannews. 
Sabotage and theft through siphoning have become a major issue as well as contributing to environmental degradation. Damaged lines may go un-noticed for days, weeks, months or years, and repair of damaged pipes takes even longer time. Oil siphoning has become a big business with the stolen oil quickly making its way into the black market. While the popularity of selling stolen oil increases, the number of deaths associated with it is also increasing. In late December, 2006 more than 200 people were killed in Lagos due to pipeline explosion. ${ }^{54}$ Experts have also urged the Federal Government to take positive steps to revive and maintain the ailing and dilapidated refineries and push for an enabling environment to encourage investors to build new refineries in Nigeria. ${ }^{55}$

For Abiye Membere ${ }^{56}$ the land, air and waters of the Delta have been polluted and poisoned over many decades. And for this, the international oil companies must take a greater share of the responsibility even though they are not the sole cause. Sabotage, theft and illegal refineries also seriously share in the blame. But corrosion, out-dated piping and maintenance malpractice by some of these large corporations had led to hundreds of small and large scale spills over the years. For instance, the Trans Niger Pipeline which transports around 150,000 bpd of crude oil from wells across the Niger Delta through the creeks and impoverished villages of Ogoniland and Ogu-Bolo to the giant oil terminal at Bonny is rusting away nearly 50 years old and known to spring leaks and spills. And it is, according to John Vidal, ${ }^{57}$ one of the most sabotaged lines in the world with local communities accused by Shell of making over 20 attempts to tap oil from it in 2012 alone.

The environmental loss to illegal oil bunkering in Nigeria is estimated at $\$ 1$ trillion. Crude oil theft and illegal artisanal refining are widespread and stifle traditional community life; they have outstripped fishing and farming as a contributor to community Gross Domestic Product and they are damaging and supplanting legitimate economic activities of the communities. By some estimates, the loss is almost 400,000 barrels per day. But oil theft invariably entails the destruction of pipelines and once detected would mean the closure of the pipelines to effect repairs which costs a lot of time, money, energy and man hours and power. The vicious circle of vandalism, detection, repairs and back to vandalism is what results into the estimated losses: part of which would be the actual stolen crude. ${ }^{58}$

\section{Ideological Narratives}

On the whole, the scourge of oil theft has also transformed the narrative on environmental pollution in the delta. Currently, as revealed from the foregoing, two competing narratives have developed each driven by the two ideologically opposed actors in the oil theft and illegal refining debate. The first narrative is that of the corporate state complex and the

\footnotetext{
${ }^{54}$ Environmental Issues in the Niger Delta, Academic Journals (Retrieved: May 21, 2007). http://en.m.wikipedia.org/wiki. October 3, 2013.

${ }^{55}$ Experts Advocates Speedy Passage of Petroleum Industry Bill. www.ngrguardiannews. July 31, 2013.

56 Abiye, M., Time for Change: New Opportunities, Partnerships and our Energy Future. www.vanguardngr.com. August 12, 2013.

57 Vidal, J., F1bn a Month: The Spiraling Cost of Oil Theft in Nigeria. www.theguardian.com. October 5, 2013.

58 Okere, R., Government loses \$1 trillion to Illegal Oil Bunkering. www.ngrguardiannews. August 16, 2013.
} 
second is the critical narrative subscribed to by non-governmental organizations and rights activists. The first narrative holds with caution the view that oil theft is the dominant cause of pollution and environmental degradation while the second narrative subscribes to the tenacious view that weak regulation, aged infrastructure and lack of transparency on the part of the corporate state complex are responsible. ${ }^{59}$

Corporations hold tenaciously to the argument against oil theft because it has two legal defensive advantages. Apart from using it as a bulwark to explain away their inability to implement remediation due to the added argument of community blockade and militant resistance, it also enables the corporations to absolve themselves from criminal and civil liabilities. There is always therefore, the blame game that goes on since oil theft has acquired a certain degree of notoriety in the delta. Oil theft therefore, seems to be a very strong alibi for the corporations because of these two views. It is very likely that large scale theft committed by corporate state complex insiders are less likely to give rise to large scale environmental impact in that experts are involved than a small scale theft involving militants and communities in which there is the lesser likelihood of managing the process of siphoning in order to reduce the environmental impact. But worst of all is sabotage which is abinitio targeted at the struggle for regional justice and therefore immoderate and uninformed by any economic calculations and considerations rather than wanton damage. While sabotage may lead to large scale spill, theft may not. ${ }^{60}$

But determining the extent to which oil theft, sabotage, weak regulation and infrastructure influence environmental degradation, according to Amnesty International, requires full transparency on the part of the corporations and the state not campaign and propaganda machineries spewing out bloated and conflicting estimates and data. ${ }^{61}$ It also requires the full appreciation by the state and the industry of the fundamental needs and rights of the indigenous people to participate in their economy and not necessarily the use of military forces against militancy and incipient show of rights of inclusion, claim of right and self determination in theft as it is elementary that two wrongs cannot make a right.

\section{Regularity of Theft Occurrence}

Multinational oil companies and the Federal government seem to be loosing the battle to the perpetrators of the illegal trade of vandalism and oil theft and the perpetrators are not perturbed by the various efforts being put in place to curb the menace. Amongst others, Shell attributed decline in its earnings in 2013 to rising cost and a surge in oil theft making it to sell four oil blocks. ${ }^{62}$ The four blocks are sitting in the heart of the eastern Niger Delta, an area particularly hit by crude oil theft. Shell is also selling the Nembe Creek Trunk Line, a key oil transport artery which had to be shut repeatedly after attacks by thieves. The asset sales represent a dramatic retreat by international oil and gas majors from the core of Nigeria's oil

59 Oil theft in Niger Delta doesn't Explain all the Spills. www.legaloil.com.

http://livewire.amnesty.org/2013/09/24. September 24, 2013.

${ }^{60} \mathrm{Id}$

${ }^{61} \mathrm{Id}$

${ }^{62}$ Okere, R., Counting the Cost of Pipeline Vandalism. www.ngrguardiannews August 14, 2013. 
industry. All the four blocks and the Nembe Creek Trunk Line feed the Bonny Terminal, Nigeria's oldest export facility commissioned by Shell in $1961 .^{63}$

Points of occurrence of pipeline tapping in Nigeria are mind-boggling. The vigilance of all Nigerians is necessary to check illegal oil bunkering, which had drastically reduced the socioeconomic potentials of the nation. For instance, Shell had to shut down the Trans Niger Pipeline following reports of new leaks 10 days after the line was repaired. The company claimed that a total of 189 crude theft points had been repaired on the 24 inch and 28 inch Trans Niger Pipeline between January and September, 2013. Shell stated that it was 'dealing with a social tragedy, an environmental crisis and a sad waste of resources.' It found it difficult to safely operate its pipelines without having to shut them frequently to prevent leaks from illegal connections impacting the environment. And ironically, the thieves use Shell's repair windows to prepare and launch fresh illegal connections when it restarts production. ${ }^{64}$ The Trans Niger Pipeline has been repeatedly targeted and closed down five times since early July, 2013 due to multiple leaks from crude theft. ${ }^{65}$

In fact, the Trans Niger Pipeline case is notorious. Company contractors were repairing one section of the pipeline when an explosion occurred and the official investigation team believed that the accident followed a botched attempt to steal tens of thousands of barrels of crude oil. Even as one group of engineers was removing illegal taps on the line, another group was installing equipment to allow huge amounts of oil to be siphoned straight into large barges where it would be taken to sea to waiting tankers bound for Europe and the US. ${ }^{66}$ Nigerian Agip Oil Company (NAOC) on the other hand lost 20,000 bpd to alleged crude theft in the Niger Delta region leading to shutdown of production early 2013 to effect repairs on 162 vandalized points caused by crude oil thieves. ${ }^{67}$

To Andrew Yakubu of Nigerian National Petroleum Corporation, (NNPC) ${ }^{68}$ the corporation had over 774 break points since August 2012 from Atlas Cove to Ilorin. It recorded 181 break points between Atlas Cove and Mosimi depot; and from Mosimi to Ibadan it had 421 ruptured points and from Mosimi to Ore it recorded 50 vandalized points; and between Ibadan and Ilorin it had 122 break points. Vandalism of the vast artery of pipelines led to trucking and trucking has its attendant cost of maintaining a massive fleet of over 1,212 trucks for bridging into the hinterlands. According to Gbenga Komolafe of NNPC and PPMC Nigeria lost about N163 billion from crude oil and petroleum products pipelines from 2009 to 2012 alone not including associated costs: economic sabotage, environmental degradation and destruction of national assets. ${ }^{69}$ Data available from NNPC further revealed that 53 break

\footnotetext{
${ }^{63}$ Editor, Shell Consortium to Sell 4 Oil Blocks in Nigeria. http://businessdayonline.com. October 11, 2013.

${ }^{64}$ Agencies, Shell raises Alarm over Crude Oil Theft in Nigeria. www.globaltimes.cn/com. October 11, 2013.

${ }^{65} \mathrm{Id}$

${ }^{66}$ Sulaimon, S., Nigeria's Oil Production unsteady amid Crude Theft Vandalism. www.ngrguardiannews.com. September 25, 2013.

${ }_{67}$ Okere, R., Counting the cost of Pipeline Vandalism. www.ngrguardiannews August 14, 2013.

${ }^{68} \mathrm{Id}$

${ }^{69} \mathrm{Id}$
} 
points were discovered along the $97 \mathrm{~km}$ Nembe-Creek Trunk line in the first quarter of $2013 .^{70}$

The vandals operate with high sophisticated equipment to carry out their criminal activities and have associations which organizes activities and remit bribe money to security personnel that they regard as threat to their operations. They have several ruptured points which they seal off immediately after siphoning fuel. Ferdinand Esiegwu of Nigerian Security and Civil Defence Corps (NSCDC) claimed that in six months 13 tankers were burnt on the directive and supervision of government and a total of 24 different cases with 37 suspects unlawfully dealing with petroleum products were also recorded in Edo State Command alone. ${ }^{71}$

The regularity is such that the state has formed the opinion that the country may not survive from the setback caused by the current vandalism of oil and gas installations in the next 20 years yielding grounds to the suggestion that there is lack of political will from the state in dealing with the incidence which requires the severest punishment. ${ }^{72}$

\section{Contracting Security to Militants}

For Alohan Juliet, ${ }^{73}$ several attempts have been made by the state to tackle the challenge of oil theft but not to much avail. The collaboration between NNPC and other international agencies, maritime operation committee of Army, Air-force, Navy, Customs, Police, SSS and the judiciary has not done much good of confronting the open secret that Nigeria, according to the Economic Magazine of August 4, 2012, is the world's capital of oil theft. ${ }^{74}$ Even the juicy pipeline protection contract which the Wall Street Journal ${ }^{75}$ claimed was awarded to Mujaheed Asari Dokubo (\$9m), Ebikabowei Boyloaf $(\$ 3.8 \mathrm{~m})$, Ateke Tom $(\$ 3.8 \mathrm{~m})$, and Tompolo Ekpumukpolo ( $\$ 22.9 \mathrm{~m})$, all ex-militants, equally ended up as yet another drain on the pipelines.

It has been established that the heightened attacks on the pipelines coincided with the ongoing negotiation between the Federal Government and some of the ex-militants for the renewal of the pipelines surveillance contracts amidst pressure from other militants to be factored into the deal. In fact, the revocation of the oil pipeline protection contracts which were awarded to former agitators is one of the factors responsible for the rise of oil bunkering in the Niger Delta in that it has forced the natives to resort to other jobs in a bid to survive and the next phase of the crisis may be worse than the previous one if the state fails to implement the terms of the amnesty to the letter. This has led Governor Oshiomhole of Edo

\footnotetext{
${ }^{70}$ Alohan, J., Crude Oil Theft: Act of Terrorism or lack of Political Will? www.legaloil.com. November 10, 2013.

${ }^{71}$ Ex-Minister of Petroleum, Allison Madueke, Id.

${ }^{72}$ Alohan, J., Loc. Cit.

${ }^{73}$ Igwe, U., Oil theft: What Nigeria must do. www.legaloil.com. July 10, 2013.

${ }^{74}$ Adeniyi, O., Oshiomhole, Massive Oil Theft Inexcusable. www.legaloil.com. July 14, 2013.

75 Ahamefula, O., Nigeria: Oil theft - We are yet to Catch the Big Thieves, says Mittee.

http://m.allafrica.com/stories. October 14, 2013.
} 
State to express the concern that no nation should live with this kind of situation in which the state surrenders its national assets to thieves.

The concept of individual contracting instead of communally based contract has also been attacked by Mittee Ledum. ${ }^{76} \mathrm{He}$ argues that instead of giving the contracts to guard pipelines to an individual, the community should be given so that the youths of the community would be employed even on shift basis. Oil experts have equally assailed the ex-militants as incompetent and that the manner in which the contracts were handed over to the ex-militants under the table rather than above the table sends the wrong signals to the international community over the state's commitment to the principles of the Extractive Industry Transparency Initiative of which the state has given an affirmative action. ${ }^{77}$

However, the Jonathan Presidency came up stoutly through Kingsley Kuku in defence of the award of the contracts insisting that the choice of ex-militants such as Tompolo, Ateke, Boyloaf and Dokubo was to ensure the success of the jobs as only the natives of the Niger delta were well placed and positioned to assist security agencies in combating oil theft and tampering with the oil facilities. It was a provision of the amnesty deal, the state argued, that an appreciable means of livelihood for the ex-militants was needed to encourage them to prevail on their supporters to keep the peace. ${ }^{78}$

But the current Buhari Presidency is on a reversal mission arguing that the State will not tolerate 'an army within the army or a police within the police' and it believes that these contracts were not properly given out or are the contractors qualified for the job of pipeline security and has largely revoked the contracts. ${ }^{79}$

\section{The Guardian Prescriptions}

It is not only that the 'blowing up of things' is causing more pollution and collateral damage as contended by some stakeholders, the debate is strife that the multinational oil companies are behind the military in stifling the growth of an indigenous industrial technology. The Guardian ${ }^{80}$ submits that makeshift refining implicates the ingenuity of the average Nigerian. That ingenuity exists in several areas of our national life and is often killed at its embryonic stage. In countries where foresight is brought to bear on the development process, such ingenuity constitutes the building blocks of technological breakthroughs. Instead of simply criminalizing these outfits to the rebound of the major business interests of the multinationals,

\footnotetext{
76 Alohan, J. and Tsan. A., Tompolo, Ateke Tom's Pipeline Contracts against Global PracticeExperts. www.legaloil.com. July 3, 2013 and Alohan, J., Crude Oil theft: Act of Terrorism or lack of Political Will? www.legaloil.com. November 10, 2013.

${ }^{77}$ Daniel, S., Militants' Pipeline Protection Contract Part of Amnesty Deal - Presidency. www.legaloil.com. http://www.vanguardngr.com. July 17, 2013.

78 Nwabughiogo, L., Pipeline Surveillance: Buhari to Revoke Jonathan's Contract to OPC, Ex-

Militants. www.vanguardngr.com May 16, 2015.

${ }^{79}$ Editorial, Illegal Refineries in Niger Delta. www.ngrguardiannews. February 3, 2012. ${ }^{80} \mathrm{Id}$
} 
the Guardian ${ }^{81}$ further argues, government ought to have found ways to help them structure and achieve transformation. Besides, they ought to be licensed and structured into efficient production units underlined by quality control. The existence of illegal refineries ought to be seen as a manifestation not necessarily of criminal intent, but of survival initiatives that ought not to be suppressed. Rather, such initiatives ought to be harnessed within the ambits of the law as necessity is the mother of invention. Two reactions to the editorial views of the Guardian $^{82}$ were positive and apt:

'I think these men are heroes who refine oil illegally. What they need is funds to refine on a bigger scale and in safer way. No mention was made of the quality of their products and how to improve on them. Release them and equip them.' 'Please help these ... improve their business and stop harassing them. Help them with capital and technological empowerment to do their business. I salute their creativity, they just need help and support from the government that is just stealing their money.'

To Professor Bolaji Akinyemi, ${ }^{83}$ 'here are Nigerians who obviously understand the rudimentary process of producing refined PMS (Prime Motor Spirit) and instead of encouraging them, we punish them.'

To the Guardian, ${ }^{84}$ solving the problem of unemployment entail creating opportunities and encouraging independent initiatives of the people. There is no doubt that illegal refineries provide employment for some people in the area ironically reputed for its poverty rather than opulence and this, despite decades of oil exploitation. Therefore, a creative transformation of the makeshift refineries could provide further employment for the people and redirect their energies from social vices to productive initiatives.

The paper which laments that it is shameful that the deficit in the industry occupies the front burner of national discourse not for reasons of celebrating major strides but for wrong reasons of continuing incompetence and sleaze has the support of Bolaji Akinyemi. ${ }^{85} \mathrm{He}$ canvasses that booming and smashing refineries have been the standard solution to the problem of illegal refineries, but the problem is that it is not the solution. 'We should stop burning and destroying as a policy... and regard building up our own domestic technology as a priority and start pursuing policies towards that end'. The defunct Biafra Republic refined petrol during the civil war over four decades ago yet in $21^{\text {st }}$ century the Federal Republic of Nigeria has not come of age either in local technology for the running of the industry or in the ability to sustain the imported technology upon which the industry is dependent.

A government commissioned report found that oil theft and illegal refining of oil have become widespread to the extent of stifling traditional life of oil producing communities

\footnotetext{
${ }^{81}$ Id

${ }^{82}$ Akinyemi, B., Thinking Outside the Box: New Approaches to Old Demons. www.vanguardngr.com June 24, 2015.

${ }^{83} \mathrm{Id}$

${ }^{84}$ Akinyemi, B., Op. Cit.

${ }^{85}$ Uwemedimo, N. Government must Deregulate the Downstream Sector: Ayoyinka Jegede.

www.ngrguardiannews, June 6, 2015.
} 
turning them into ganglands; and according to Kuku, many vulnerable and impressionable young people now aspire to join this growing but extremely dangerous and certainly illegal and immoral business. ${ }^{86}$ In fact unemployment among the people of Niger delta is so high that it leads in part to the formation of militias and gangs that run illegal oil refineries found predominantly around the multinational company's main pipelines in such a way that illegal extraction of oil is the only option open to earn a living. ${ }^{87}$

\section{Conclusion}

The fact that oil theft and illegal refineries in the Niger Delta have assumed an industrial and international dimension is no longer debatable. The damages which have resulted are equally enormous on all the stakeholders. It appears equally clear that the military option of suppressing the activities of the refiners have not helped matters. While it may seem abnormal to allow the theft and refining grow and fester to the detriment of the state and the industry, legal control of same may seem a better approach as that will yield a win-win situation.

The general disconnect between the implementation of recommendations of government panels and committees on the oil and gas sector has been revealed in this paper. While the Idika Kalu Special Task Force may have recommended for the deregulation of the oil and gas sector of the Nigerian economy and particularly the privatization of the refineries, the State does not seem to be ready to carry out the recommendation. Rather, it appears to be digging in and engaging the militants and natives accused of oil theft in the security of the critical assets. The posture of the State has failed to send the right signal to private interests in the downstream sector of the industry and same does not seem to have the potentials for encouraging indigenous technology transfer.

\section{Recommendation}

The government should have the traction to abide by and carry out the recommendations of committees it has set up to look into critical problems affecting the economy instead of sweeping the recommendations under the carpet and continuing to take steps that are not in the interest of the economy in the long run. The debate for deregulation has gone full circle and the implementation appears to be the better way out of the scourge of oil theft and its associated crimes.

The Nigerian state should review its current laws against local oil refineries in the creeks and put in place liberal legal regimes that would accommodate and regulate the existence of illegal refineries. They (illegal refineries) seem to be one of the ways out of the technological deficits calling for attention in the Nigerian oil and gas economy: That is, the development and advancement of the technology beneath indigenous oil refineries and its potentials to create job and connect the two economies.

\footnotetext{
${ }^{86}$ Duru, E. A., Addressing Oil Theft, Illegal Bunkering in Niger Delta. http://dailyindependentnig.com. August 26, 2013.

${ }^{87}$ Counting the Costs of the Niger Delta's Broken Oil Industry. http://theworldoutline.com. September 23, 2013.
} 


\section{References}

1. Abiye, M., Time for Change: New Opportunities, Partnerships and our Energy Future. www.vanguardngr.com. August 12, 2013.

2. Adekunle, O., Replicating the Gains of Deregulation in Petroleum Sector (2). www.vanguardngr.com. January 1, 2012.

3. Adeniyi, O., Oshiomhole, Massive oil theft inexcusable. www.legaloil.com. July 14, 2013.

4. Adeola, Y., JTF Destroys Largest Illegal Refineries' Site in Niger Delta. http://dailyindependentnig.com. May 7, 2013.

5. Adewale, M., Nigeria's Long Emergency, http://mobile.nytimes.com. September 22, 2013.

6. Agencies, Shell Raises Alarm over Crude Oil Theft in Nigeria. www.globaltimes.cn/com. October 11, 2013.

7. Ahamefula, O., Nigeria: Oil theft - We are yet to Catch the Big Thieves, says Mittee. http://m.allafrica.com/stories. October 14, 2013.

8. Alohan, J., and Tsan, A., Tompolo, Ateke Tom's Pipeline Contracts against Global Practice - Experts. www.legaloil.com. July 3, 2013.

9. Alohan, J., Crude Oil Theft: Act of Terrorism or Lack of Political Will? www.legaloil.com. November 10, 2013.

10. Akinosho, T., The News Interview: Flawed Implementation of Amnesty Programme caused Oil Theft in the Niger Delta. http://mobile.saharareporters.com. April 15, 2013.

11. Amaize, E., Oyadonga, S., and Onoyume, J., Oil: The Conspiracy that Robs Nigeria of Billions of Dollars. www.vanguardngr.com. August 25, 2013.

12. Amanze-Nwachukwu, C., FG may Dump Bayelsa, Kogi Greenfield Refinery Projects as only Lagos Viable. www.thisdaylive.com August 25, 2013.

13. Asu, F., JTF Discovers Illegal Crude Loading Points, Impound Barges. http://businessdayonline.com. July 4, 2013.

14. Audu, L. O., Sepecial Report: Crude Refining in Niger Delta Communities. www.westafricainsight.org . January, 2013.

15. Ayanruoh, F., Nigeria - Cold Facts of Crude Oil Theft. www.vanguardngr.com. October 15, 2013.

16. Chatham House, Nigeria Oil Theft a Global Criminal Enterprise. http://pmnewsnigeria.com. September 19, 2013. 
17. Conflict in the Niger Delta. http://en.m.wikipedia.org/wiki. October 14, 2014

18. Counting the Costs of the Niger Delta's Broken Oil Industry. http://theworldoutline.com. September 23, 2013.

19. Daniel, S., Militants' Pipeline Protection Contract Part of Amnesty Deal Presidency. www.legaloil.com. http://www.vanguardngr.com. July 17, 2013.

20. Daniel, S., Why Niger Delta Oil Theft can't Stop - Boyloaf. www.vanguardngr.com. September 7, 2013.

21. Duru, E. A., Addressing Oil Theft, Illegal Bunkering in Niger Delta. http://dailyindependentnig.com. August 26, 2013.

22. Ebenezer, A., Hard Time Awaits Criminal on Niger Delta Waterways - Naval Boss. www.tribune.com.ng.

23. Ebiri, K., How Bunkering puts Nigeria's Oil Export in Jeopardy. www.ngrguardiannews. September 29, 2013.

24. Editorial, Illegal Refineries in Niger Delta. www.ngrguardiannews. February 3, 2012.

25. Editor, Shell Consortium to Sell 4 Oil Blocks in Nigeria. http://businessdayonline.com. October 11, 2013.

26. El-Rufai, N, A., Impunity, Injustice and Insecurity: What is the Role of Law? http://premiumtimesng.com. May 23, 2013.

27. Environmental Issues in the Niger Delta, Academic Journals (Retrieved: May 21, 2007). http://en.m.wikipedia.org/wiki. October 3, 2013.

28. Ese, S., Illegal Bunkering Cause of Arms Build up, says Dickson. July 9, 2013.

29. Essiet, D., How to make Private Refineries Viable. www.thenationonlineng.net. December 12, 2011.

30. Experts Advocates Speedy Passage of Petroleum Industry Bill. www.ngrguardiannews. July 31, 2013.

31. FG to Approve Licenses for Private Refineries says Jonathan. http://www.premiumtimesng.com.

32. Flash: Pollution Escalates in Niger Delta as Military set Ablaze 1,819 Illegal Refineries, 861 Boats Carrying Crude, 51 Tanker Trucks. http://newsbytesnow.com. August 16, 2013.

33. Igwe, U., Oil Theft: What Nigeria must do. www.legaloil.com. July 10, 2013.

34. John, V., Flbn a month: The Spiraling Cost of Oil Theft in Nigeria. www.theguardian.com. October 5, 2013. 
35. John, V., Niger Delta Oil Spill Victims Reject 'Derisory' Shell Compensation Offer. www.theguradian.com . September 13, 2013.

36. Jonathan, Sell the Refineries now. http://mobile.punchng.com. August 18, 2013

37. Lagos (AFP), Nigerian Crude Oil Stolen on an Industrial Scale. www.vanguardngr.com. September 20, 2013.

38. Nigeria: Poor Oil Spill Clean-up Methods Affect Niger Delta Communities. http://m.irinnew.org/report. February 7, 2008.

39. Nwabughiogo, L., Pipeline Surveillance: Buhari to Revoke Jonathan's Contract to OPC, Ex-Militants. www.vanguardngr.com May 16, 2015.

40. Obadiah, M., Nigeria's Oil Pillage Crisis. http://businessdayonline.com. September 30, 2013.

41. Ogbechie, G., Subsidy Probe spurs new Down-stream Investments - Rain Oil CEO. http://mobile.punchng.com. August 1, 2013.

42. Oil Theft in Niger Delta doesn't Explain all the Spills. www.legaloil.com. http://livewire.amnesty.org/2013/09/24. September 24, 2013.

43. Olayinka, C., Nigeria is Oil-dependent, not Oil-rich, says Asobie. www.ngrguardiannews. October 16, 2013.

44. Olayinka, C., South-South Governors Lead Campaign for Passage of PIB. www.ngrguardiannews.

45. Ojakorotu, V., Military and Oil Violence in Niger Delta. Journal of Energy Security. www.ensec.org. August 27, 2009.

46. Okere, R., Counting the Cost of Pipeline Vandalism. www.ngrguardiannews August 14, 2013.

47. Okere, R., Government Loses \$1 trillion to Illegal Oil Bunkering. www.ngrguardiannews. August 16, 2013.

48. Okere, R., How Investors Stall Government's Drive for Private Refineries. www.ngrguardiannews.com. December 9, 2012.

49. Okere, R., Why Investors are Shunning Nigeria's Oil, Gas Sector. www.ngrguardiannews. September 9, 2013.

50. Oyadongha, S., Grounded Crude Oil Barge: Navy Arrests Tug Boat, 6 Suspects. www.vanguardngr.com. August 15, 2013.

51. Oyadongha, S., Governor's Forum Set to Check Oil Theft, says Uduaghan. www.vanguardngr.com. August 13, 2013. 
Journal DOI: www.doi.org/10.46654/SJALR

52. Shell Accused over Misleading Figures on Nigeria Oil Spills. www.amnesty.org/en/news. January 25, 2011.

53. Six new Refineries Hurray! But not yet Uhuru. www.vanguardngr.com. July 9, 2012.

54. Sulaimon, S., Nigeria's Oil Production Unsteady Amid Crude Theft Vandalism. www.ngrguardiannews.com. September 25, 2013.

55. Udo, B., Nigeria to Integrate Trained Ex-militants into Oil Industry. www.legaloil.com. http://premiumtimesng.com/business/149388. November 11, 2013. 